\title{
The largest reference range study for hematological parameters from Turkey: A case control study
}

\author{
Türkiye' den hematolojik parametrelerin en büyük referans aralığı çalışması: Bir vaka-kontrol \\ araştirması
}

Nilgün Tekkeşin ${ }^{1}$, Hüseyin Bekoz ${ }^{2}$, Faruk Tükenmez ${ }^{3}$

\begin{abstract}
Objective: Accurate, reliable laboratory reference ranges are essential for effective clinical evaluation and monitoring. We present robust reference ranges established for hematology parameters using the Sysmex XT2000i analyzer.
\end{abstract}

Methods: Blood samples were taken from 17409 healthy adults (19 to 49 years, $51.4 \%$ men and $48.6 \%$ women) and routine hematology analysis performed. Patients were assessed as healthy on the basis of a medical history and routine medical examinations. Serum hematinic assays (vitamin B12, folate, iron and ferritin) were also analyzed in order to exclude the potential anemia existence.

Results: There was a statistically significant difference $(p<0.001)$ between men and women, with the former showing higher $\mathrm{CBC}$ values, except WBC, neutrophil and platelet counts compared to females. Several differences were observed when compared to previously established values from Turkey, most notably in leucocytes and platelets. Our findings for CBC parameters, except leucocyte count and MCV are in general agreement with previously published data from more limited trials undertaken in other countries.

Conclusions: In spite of the uncontrolled factors influencing hematological values, this study permitted to establish the new hematological reference values in Turkey, especially living near sea level. In the absence of previously detailed investigated hematological reference values in Turkey, we offered to use these results for clinical management of Turkish patients and interpretations of laboratory data for research purpose. J Clin Exp Invest 2014; 5 (4): 548-552

Key words: Complete blood count, hematology, reference range

\section{ÖZET}

Amaç: Doğru, güvenilir laboratuvar referans aralıkları etkili klinik değerlendirme ve izleme için gereklidir. Biz hematoloji parametreleri için belirlenmiş mevcut referans aralıklarını Sysmex XT2000i analizörü kullanarak sunuyoruz.

Yöntemler: kan örnekleri 17409 sağlıklı erişkinden (yaş aralığı, 19 ile 49 yıl arasında, \%51,4 erkek ve \%48,6 kadın) alındı ve rutin hematoloji analizi yapıldı. Hastalar, tıbbi geçmişleri ve rutin muayenelerine dayanarak sağlıklı olarak değerlendirildi. Serum hematinik testleri (vitamin B12, folat, demir ve ferritin) de çalışılarak potansiyel anemi varlığı hariç tutuldu. Bulgular: Kadın ve erkek arasında belirgin istatistiksel farklılık $(p<0,001)$ olup erkeklerde kadınlara göre tam kan sayımı parametreleri, beyaz küre hücreleri, nötrofil ve trombositler hariç daha yüksekti. Daha önce Türkiye'den bildirilen değerler ile karşılaştırıldığında başta lökositler ve trombositler olmak üzere birçok farklııılar tespit edildi. Tam kan sayımı parametreleri bulgularımız, diğer sınırlı sayıda katılımcının yer aldığı ülkelerden elde edilen yayınlanmış verilere göre kıyaslandığında ise lökosit sayısı ve MCV hariç genel bir uyumluluk içindeydi.

Sonuçlar: Hematolojik değerleri etkileyen kontrol edilemeyen faktörlerin aksine, bu çalışmada, Türkiye' de özellikle deniz seviyesinde yaşayanlar için yeni hematolojik referans değerlerinin oluşturulmasına izin vermiştir. Türkiye'de daha önce ayrıntılı incelenen hematolojik referans değerleri yokluğundan dolayı, bu sonuçların Türk hastaların klinik açıdan yönetimleri ve araştırma amaçlı laboratuvar verilerinin yorumlanması adına kullanılmasını öneriyoruz.

Anahtar kelimeler: Tam kan sayımı, hematoloji, referans aralığı

\footnotetext{
${ }^{1}$ Biochemistry Department, Central Laboratory, Memorial Şişli Hospital, Istanbul, Turkey

${ }^{2}$ Hematology Department, Medipol University, Istanbul, Turkey

${ }^{3}$ Cardiovascular Surgery Department, Şişli Hospital, Istanbul, Turkey
}

Correspondence: Nilgün Tekkeşin, Biochemistry Department, Central Laboratory, Memorial Şişli Hospital, Istanbul/Turkey Email: niltek@hotmail.com 


\section{INTRODUCTION}

The hematological reference values were determined many years ago for the Caucasian populations [1-3]. Because of the absence of a reference range for hemoglobin concentration and other blood cell values, reference values obtained from a predominant population living in North America and Europe [4]. However, there are some discrepancies between studies which may be due to different factors such as age, sex, geographic origin, altitude, and ethnic origin [5].

Istanbul is a Western Turkish city, with an altitude below 1000 meters. The importance of this study was increased as the trial consisted of a wide range of citizens who came from all other regions of the country to live in this city. The study therefore included subjects, with different geographic origins some of whom may carry genetic hemoglobinopathies. Several studies have established reference values for total blood count for Turkish cities [6-8]. However, there has been no study so far that has assessed hematology reference intervals in a controlled, systematic manner among asymptomatic adults who would otherwise be eligible as healthy subjects in clinical trials in this region.

Based on these reasons, in order to achieve a better interpretation of hematological results, we established hematological reference values by studying healthy adults gathered from hospital check-up center in Istanbul. The reported values may also serve as a source of reference and comparison for laboratories working in similar environments.

\section{METHODS}

Our study protocol complied with the recommendations of the National Committee for Clinical Laboratory Standards (NCCLS) [9-11] and the International Federation of Clinical Chemistry and Laboratory Medicine (IFCC) [12]. The institutional committee for medical ethics approved the study protocol, and all patients gave informed consent. Patients were assessed as healthy on the basis of a medical history and routine medical examinations. Serum hematinic assays (vitamin B12, folate, iron and ferritin) were also analyzed.

Between January 2010 and December 2012, check-up patients $(n=17409)$ of both sexes $(51.4 \%$ men and $48.6 \%$ women) and between 19 and 49 years of age were selected at the check-up service centre.
All samples were collected between 9.00 a.m. and 11.30 a.m. after a 15 minutes recumbent rest and analysed within 2 hours. Moreover, a peripheral blood film was done in order to detect abnormalities of red blood cell. All samples were tested for human deficiency virus (HIV), hepatitis B virus (HBV), and hepatitis $\mathrm{C}$ virus $(\mathrm{HCV})$ viral infections and syphilis. The criteria for inclusion in our study were the following: negativity of all serological tests for viral infections, and absence of hypochromia on peripheral blood smear. None of them had a history of blood donation.

A Sysmex XT-2000i (Sysmex Corp., Kobe, Japan) automated hematology analyzer was used and calibrated and maintained according to the manufacturer's instructions. Intra and interassay coefficient of variation (CV) ranged from totally $0.3 \%$ to $1.5 \%$ and $0.6 \%$ to $1.4 \%$ for all parameters, respectively.

\section{Statistical analysis}

Reference intervals for different subclasses (males and females) were separated according to NCCLS guidelines [9]. Complete blood count (CBC) parameters were examined for normal distribution from histograms, $Q-Q$ normality and Box plots, tvalues (Skewness/SE Skewness), kurtosis and significance levels calculated from the KolmogorovSmirnov and Shapiro-Wilk tests of normality. The differences were statistically significant when $p<$ 0.05 . Reference ranges for near normally distributed parameters were calculated using mean \pm 2 SDs (standard deviation). As nonparametric statistical methods are less accurate than their parametric counterparts, non-normally distributed parameters data were transformed logarithmically using the log natural transformation and the antilog of the 2.5th and 97.5th percentiles. All statistical analyses were carried out using GraphPad Prism ver. 3.0 (San Diago, USA).

\section{RESULTS}

A total of 20369 potential healthy adults were screened, of whom 17409 (85,4\%) were included in the final analysis with a mean age of 39 years for men and 34 years for women (range 19-49). The means, SD values, and 95th percentile reference values according to gender for red blood cell (RBC) parameters were shown in Table 1, white blood cell (WBC) parameters were given in Table 2, and platelet counts in Table 3. There was a statistically significant difference $(p<0.0001)$ between men 
and women, with the former showing higher $\mathrm{CBC}$ values, except WBC, neutrophil and platelet counts compared to females. Our results as well as those of other Turkish cities were displayed in Table 4.

Table 1. Mean plus/minus standard deviation and $95^{\text {th }}$ percentile reference values by gender for red blood cell parameters

\begin{tabular}{|c|c|c|c|c|c|c|}
\hline $\begin{array}{l}\text { Red Cell } \\
\text { Parameters }\end{array}$ & $\begin{array}{c}\mathrm{RBC} \\
\left(\times 10^{6} / \mu \mathrm{L}\right) \\
\end{array}$ & $\begin{array}{c}\mathrm{Hb} \\
(\mathrm{g} / \mathrm{dL})\end{array}$ & $\begin{array}{l}\text { Hct } \\
(\%)\end{array}$ & $\begin{array}{l}\text { MCV } \\
(\mathrm{fL})\end{array}$ & $\begin{array}{c}\mathrm{MCH} \\
(\mathrm{pg})\end{array}$ & $\begin{array}{l}\mathrm{MCHC} \\
(\mathrm{g} / \mathrm{dL}) \\
\end{array}$ \\
\hline $\begin{array}{lll}\begin{array}{l}\text { M a I } \\
(n=8960)^{*}\end{array} & \text { e Mean } \pm \text { SD } \\
(\% 95)\end{array}$ & $\begin{array}{l}5.25 \pm 0.37 \\
(4.50-6.00)\end{array}$ & $\begin{array}{c}15.27 \pm 0,92 \\
(13.42-17.11)\end{array}$ & $\begin{array}{c}44.92 \pm 2.49 \\
(33.97-44.54)\end{array}$ & $\begin{array}{c}86.65 \pm 4.54 \\
(80.56-94.73)\end{array}$ & $\begin{array}{c}29.11 \pm 1.70 \\
(27.70-32.51)\end{array}$ & $\begin{array}{c}33.99 \pm 0.99 \\
(32.00-35.97)\end{array}$ \\
\hline $\begin{array}{l}\text { F e m a I e Mean } \pm \text { SD } \\
(n=8449)^{*}\end{array}$ & $\begin{array}{l}4.52 \pm 0.36 \\
(3.78-5.25)\end{array}$ & $\begin{array}{c}12.88 \pm 0.92 \\
(11.03-14.72)\end{array}$ & $\begin{array}{c}39.01 \pm 2.51 \\
(32.67-44.04)\end{array}$ & $\begin{array}{c}85.56 \pm 5.36 \\
(79.83-93.29)\end{array}$ & $\begin{array}{c}28.58 \pm 2.09 \\
(26.39-32.76)\end{array}$ & $\begin{array}{c}33.01 \pm 1.03 \\
(30.94-35.07)\end{array}$ \\
\hline
\end{tabular}

${ }^{*} p$ values $<0,001$; statistically significant difference between males and females RBC: red blood cell, Hb: hemoglobin, Hct: hematocrit, MCV: mean cell volume

$\mathrm{MCH}$ : mean corpuscular hemoglobin, $\mathrm{MCHC}$ : mean corpuscular hemoglobin concentration

Table 2. Mean plus/minus standard deviation and 95th percentile reference values by gender for WBC parameters

\begin{tabular}{|c|c|c|c|c|c|c|c|}
\hline $\begin{array}{l}\text { WBC } \\
\text { Parameters }\end{array}$ & $\begin{array}{l}\text { WBC } \\
\left(\times 10^{3} / \mu L\right)\end{array}$ & $\begin{array}{c}\text { WBC } \\
\left(\times 10^{3} / \mu \mathrm{L}\right)\end{array}$ & $\begin{array}{c}\text { Neutrophils } \\
(\%)\end{array}$ & $\begin{array}{c}\text { Lymphocytes } \\
(\%)\end{array}$ & $\begin{array}{c}\text { Monocytes } \\
(\%)\end{array}$ & $\begin{array}{c}\text { Eosinophils } \\
(\%)\end{array}$ & $\begin{array}{c}\text { Basophils } \\
(\%)\end{array}$ \\
\hline $\begin{array}{l}\text { Male } \\
(n=8960)^{*}\end{array}$ & $\begin{array}{l}\text { Mean } \pm S D \\
(\% 95)\end{array}$ & $\begin{array}{c}6.78 \pm 1.53 \\
(3.71-9.85)\end{array}$ & $\begin{array}{c}54.82 \pm 7.61 \\
(39.58-70.05)\end{array}$ & $\begin{array}{c}33.79 \pm 6.95 \\
(19.88-47.70)\end{array}$ & $\begin{array}{c}8.02 \pm 1.81 \\
(4.39-1.65)\end{array}$ & $\begin{array}{l}2.89 \pm 1.89 \\
(0.0-6.60)\end{array}$ & $\begin{array}{c}0.45 \pm 0.26 \\
(0-0.99)\end{array}$ \\
\hline $\begin{array}{l}\text { Female } \\
(n=8449)^{*}\end{array}$ & $\begin{array}{l}\text { Mean } \pm S D \\
(\% 95)\end{array}$ & $\begin{array}{c}6.88 \pm 1.78 \\
(3.61-10.45)\end{array}$ & $\begin{array}{c}58.64 \pm 8.91 \\
(40.81-76.47)\end{array}$ & $\begin{array}{c}31.20 \pm 7.93 \\
(15.32-47.07)\end{array}$ & $\begin{array}{c}7.45 \pm 1.78 \\
(3.88-11.0)\end{array}$ & $\begin{array}{c}2.25 \pm 1.76 \\
(0-5.79)\end{array}$ & $\begin{array}{c}0.43 \pm 0.26 \\
(0-0.96)\end{array}$ \\
\hline
\end{tabular}

${ }^{*} p$ values $<0,001$; statistically significant difference between males and females WBC: White blood cell

Table 3. Mean \pm SD and 95th percentile reference values by gender for platelets

\begin{tabular}{llc}
\hline & & $\begin{array}{c}\text { Platelets } \\
\left(\times 10^{3} / \mu L\right)\end{array}$ \\
\hline Male $(\mathrm{n}=8960)^{*}$ & Mean \pm SD & $238.50 \pm 46.95$ \\
& $(\% 95)$ & $(144.60-332.40)$ \\
Female $(=8449)^{*}$ & $\begin{array}{l}\text { Mean } \pm S D \\
(\% 95)\end{array}$ & $255.90 \pm 55.33$ \\
& $(145.24-366.56)$ \\
\hline
\end{tabular}

${ }^{*} p$ values $<0,001$; statistically significant difference between males and females

Table 4. Mean $\pm S D$ values by gender for some hematological parameters comparing other studies with our study in Turkey

\begin{tabular}{lcccccccc}
\hline \multirow{2}{*}{ Parameters } & \multicolumn{2}{c}{ Terzioğlu $^{6}$} & \multicolumn{2}{c}{ Başak $^{7}$} & \multicolumn{2}{c}{ Kaya $^{8}$} & \multicolumn{3}{c}{ Our study $^{2}$} \\
\cline { 2 - 9 } & $\mathrm{F}$ & $\mathrm{M}$ & $\mathrm{F}$ & $\mathrm{M}$ & $\mathrm{F}$ & $\mathrm{M}$ & $\mathrm{F}$ & $\mathrm{M}$ \\
\hline $\mathrm{RBC}\left(10^{6} / \mu \mathrm{L}\right)$ & $4.5 \pm 0.6$ & $5.2 \pm 0.7$ & $4.5 \pm 0.4$ & $5.2 \pm 0.3$ & $4.6 \pm 0.4$ & $5.1 \pm 0.4$ & $4,52 \pm 0,36$ & $5.25 \pm 0.37$ \\
$\mathrm{MCV}(\mathrm{fl})$ & $88.7 \pm 4.8$ & $85.2 \pm 10$ & $87 \pm 4.5$ & $86 \pm 4.2$ & $86.7 \pm 4.6$ & $88.2 \pm 4$ & $86,56 \pm 5,36$ & $85.65 \pm 4.54$ \\
WBC $\left(10^{3} / \mu \mathrm{L}\right)$ & & & $6.8 \pm 1.4$ & $7.2 \pm 1.5$ & $7.4 \pm 2$ & $7.8 \pm 2$ & $6.88 \pm 1.78$ & $6.78 \pm 1.53$ \\
Platelets $\left(10^{3} / \mu \mathrm{L}\right)$ & & & $235 \pm 52$ & $218 \pm 46$ & $243 \pm 55$ & $235 \pm 52$ & $255,9 \pm 55,3$ & $238.50 \pm 46.9$ \\
Hb $(\mathrm{g} / \mathrm{dL})$ & $12.4 \pm 2.3$ & $14.6 \pm 2.1$ & $13.6 \pm 1.1$ & $15.3 \pm 0.9$ & $14.6 \pm 1.6$ & $15.4 \pm 1.3$ & $12.88 \pm 0.92$ & $15.27 \pm 0.92$ \\
Hct $(\%)$ & $39.6 \pm 5$ & $44.6 \pm 9.6$ & $40.5 \pm 3.3$ & $45.2 \pm 2.8$ & $42.9 \pm 4.6$ & $45 \pm 3.9$ & $39.01 \pm 2.51$ & $44.92 \pm 2.49$ \\
\hline
\end{tabular}

RBC: red blood cell, MCV: mean cell volume, WBC: White blood cell, Hb: hemoglobin, Hct: hematocrit, F: female, M: male 


\section{DISCUSSION}

Clinical laboratory reference ranges are an important tool for identifying abnormal laboratory results and for ultimately guiding patient management decisions. Therefore, inappropriate reference values may increase the risk of either unnecessary additional investigations or failure to detect underlying disease.

In settings where reference values cannot be determined for the local population, the alternative is to use data that were collected elsewhere, usually in a developed country [13]. However, there is a general lack of published data regarding laboratory parameters for populations living in Turkey, with only a few articles that defines the reference ranges for the total blood count parameters for this country [6-8]. Data for the this study were collected in Istanbul, Turkey, which is on the West and differs in many respects (climate, altitude, main sources of income, etc.) from the Turkish highlands. In addition, the data were sampled from a diverse population. This study provides the first hematological reference ranges for Istanbul, Turkey, and to date is the largest cohort from which reference range data has been collected in Turkey.

Relevant reference ranges are required for clinical practice and research in Turkey because of the high incidence of beta-thalassemia carriers [14]. In our study, we tried to eliminate most of these abnormalities by performing standard measurements and detecting hypochromia on the peripheral blood smear. Although, this might led to the outcome of higher reference intervals for RBC and WBC according to earlier studies [15], the main limitation was the lack of hemoglobin electrophoresis to rule out beta-thalassemia carriers.

Our results are not consistent with those of the previous studies performed in several Turkish cities, excluding Istanbul [6-8]. An attempt must be made to explain why the new reference limits are generally lower than the limits described in the literature in Turkey. We believe there is no reason to question the validity of these results from the analytical point of view. It seems likely that the reference population differs from other local populations of the same ethnic mix and geographic/environmental influences. Compared to other regions, such as Erzurum, a high altitude (1869 m) site in Turkey, our reference ranges were lower, with the exception of platelet values which were much lower in the Erzurum population [8]. This is particularly coupled with the timing of venous sampling in the early morning when diurnal rhythms indicate that leukocytes are at their lowest levels.

The reference interval for hemoglobin concentration is higher than the usually accepted values $[16,17]$, but are similar to the reference intervals presented in a new study [18]. The strict control of pre-analytical factors might explain our higher red cell reference intervals compared with some of those studies. The likeliest explanation might be the stringency of the inclusion criteria that avoided the conditions known to influence counts [19]. The finding of higher values for hemoglobin, hematocrit and erythrocytes in males compared to females may be partly due to the influence of androgen on erythropoiesis. Our reference intervals for the mean cellular volume (MCV) are different than both recent and older reports $[13,16]$. MCV reference ranges for men and women were nearly below the defined cutoff values for anemia. It can be hypothesized that the low minimal range $\mathrm{MCV}$, which contrasts with the normal RBC, may be linked to the presence of undefined anemia [20]. This study illustrated the difficulty in obtaining reference values from healthy individuals for reference values for RBC series, despite detailed medical examination.

While mostly used leukocyte count values in laboratories were chosen based on earlier studies but appeared lower compared to these $[16,17]$. Reference values established in this study are similar to those of recent studies [21] with a reduction in the lower limit of both the total leukocyte count and neutrophils. Analyzers which were used to establish reference intervals in previous studies are now being replaced by instruments employing novel technologies. This might be another reason to recalculate new reference ranges, today.

In correlation with other studies [22,23], women showed higher platelet counts than men. The calculated platelet reference intervals in our study were in agreement with both earlier and recently published reports $[16,17]$. Therefore, biological variation, preand intra-analytical factors and geographical factors that may affect the platelet count could be not ignored.

Variations in hematology parameters observed in different populations emphasize the need to establish locally derived reference values [24]. Our findings for CBC parameters, except leukocyte count and MCV are in general agreement with previously published data involving more limited trials undertaken in other countries [25]. Despite the stated limitation of the study and uncontrolled factors 
influencing hematological values, we assert that the ranges generated in this study would be suitable for use in a more generalized setting. It is possible that these ranges could be extrapolated to other regions of Turkey, with similar altitudes and environments.

Based on the results from the XT-2000i, in the future we need to clarify all WBC results which are lower than $3,6 \times 10^{3} / \mathrm{uL}$. Additionally, further evaluations of the hemoglobin values for both genders are recommended. Also, the upper limit of the reference range for platelet counts should be reconsidered and recalculated, if necessary. As a result, cost can be reduced with the new reference limits, since some follow-up medical examinations may now be avoided.

\section{REFERENCES}

1. Bain BJ. Normal range in blood cells. A Practical Guide, Blackwell Scientific Publications, $3^{\text {rd }}$ edn. Oxford, UK, 2002:857-894.

2. Lewis SM, Bain BJ, and Bates I. Reference ranges and normal values. Practical Haematology, $3^{\text {rd }}$ edn Churchill Levingstone, New York, NY, USA, 2006:1124.

3. Giorno R, Clifford JH, Beverly S, Rossing RG. Hematology reference values. Analysis by different statistical technics and variations with age and sex. Am J Clin Pathol 1980;74:765-770.

4. Saxena S, Wong ET. Heterogeneity of common hematologic parameters among racial, ethnic, and gender subgroups. Arch Pathol Lab Med 1990;114:715-719.

5. Bain B, Seed M, Godsland I. Normal values for peripheral blood white cell counts in women of four different ethnic origins. J Clin Pathol 1984;37:188-193.

6. Terzioglu M, Savcı D, Ozek A, et al. Türklerde normal hematolojik değerler. Ist Univ Tıp Fak J 1953;16:193207.

7. Basak M, Gul S, Kucukardali Y, et al. Türkiye'de hemogram değerleri ile ilgili randomize referans değer çalışması. Turkey. Turk J Haematol Oncol 1998;8:6972.

8. Kaya H, Kiki I, Akarsu E, et al. Hematological values of healthy adult population living at moderate altitude (1869 m, Erzurum, Turkey). Turk J Haematol 2000;17:123-128.

9. National Committee for Clinical Laboratory Standards. How to Define and Determine Reference Intervals in the Clinical Laboratory; approved guideline $-2 n d$ edn. bC28-A2, 2000;20:13.

10. National Committee for Clinical Laboratory Standards. Procedures for collection of diagnostic blood specimens by venopuncture; approved guideline $\mathrm{H} 3$ A3. Wayne, PA, NCCLS, 1991.

11. National Committee for Clinical Laboratory Standards. Procedures for the handling and processing of blood specimens; approved guideline H18-A. Wayne, PA: NCCLS, 1990.

12. Solberg H. Approved recommendation on the theory of reference values. Part 5. Statistical treatment of collected reference values. Determination of reference limits. J Clin Chem Clin Biochem 1987;25:645-656.

13. Gilmour JW, Stevens WS, Gray C, Souza M. Laboratory expansion to large-scale international HIV preventive vaccine trials. Current Opinion in HIV and AIDS 2008;2:201-206.

14. Kocak R, Alparslan ZN, Agridag G, Baslamisli F, Aksungur PD, Koltas $S$. The frequency of anaemia, iron deficiency, hemoglobin $S$ and beta thalassemia in the south of Turkey. Eur J Epid 1995;11:181-184.

15. Pfaeffli J. Reference limits for the automated haematology analyser Sysmex XE-2100. Sysmex Journal International 2002;1:20-28.

16. Perkins $S$. Normal blood and bone marrow values in humans. In: Lee G, Foerster J, Lukens J, et al. editors. Wintrobe's clinical hematology, 10th edn. Baltimore: Williams \& Wilkins, 1998:2738.

17. Kratz A, Lewandrowski K. MGH Case records: normal reference laboratory values. $\mathrm{N}$ Engl $\mathrm{J}$ Med 1998;339:1063-1072.

18. Wakeman L, Al-Ismail S, et al. Robust, routine haematology reference ranges for healthy Adults. Int Jnl Lab Hem 2007:1-5.

19. Kaya Z. Interpretation of automated blood cell counts. Dicle Med J 2013;40:521-528.

20. Kueviakoe IM, Segbena A, Jouault H, Vovor A, Imbert M. Hematological reference values for healthy adults in Togo. ISRN Hematology 2011:1-5.

21. Nordin G, Martensson A, Swolin B, et al. A multicentre study of reference intervals for haemoglobin, basic blood cell counts and erythrocyte indices in the adult population of the Nordic countries. Scand J Clin Lab Invest 2004;64:385-398.

22. Bain BJ, England JM. Normal haematological values: sex difference in the neutrophil count. BMJ7 1975;11:473-475.

23. Bain BJ. Platelet count and platelet size in men and women. Scand J Haematol 1985;35:77-79.

24. Milman N, Byg K, Mulvad G, Pederson HS, Bjerregaard $P$. Haemoglobin concentrations appear lower in indigenous Greenlanders than in Danes: assessment of haemoglobin in 234 Greenlanders and 2804 Danes. Eur J Haemat 2001;67:23-29.

25. Houwen B. The blood cell count. In: Advanced methods in haematology. (eds. R.M. Rowan, O.W. van Assendelft \& F.E. Preston), Arnold, London, 2002:37. 